\title{
The Role of Gender and Work Experience on Career and Work Force Diversity Expectations
}

\author{
Lori J. Sallop \\ McCoy College of Business Administration \\ Texas State University \\ Susan L. Kirby \\ McCoy College of Business Administration \\ Texas State University
}

\begin{abstract}
Graduating business students at a large public university participated in a study designed to gain insight into the effects of gender and work experience on salary expectations, career characteristics, job search methods and intensity, internship participation, expected hours required and willingness to work, and sensitivity to gender issues. The study reveals that students with more work experience while in college place greater importance on higher compensation than students with less experience. The study finds that female students place greater importance on work life balance and cultural fit within the organization and are more aware of, and sensitive to, gender issues.

Over the years, several state and federal laws have been enacted to ensure gender pay equity for jobs requiring equivalent skills, effort, and/or responsibility; nonetheless, a gender pay gap still exists in which women are paid less than men for comparable positions. Part of the pay difference may be due to the fact that men and women are often drawn to different fields. Careers that tend to attract a larger percentage of men include business, finance, investment, law and engineering. Likewise, other careers tend to attract a larger percentage of women, including elementary school teaching, nursing, home health care, child care, and social work (Murrell, Frieze, and Frost, 1991). It is notable that theses careers have a significant pay disparity. Simply put, many women choose careers that pay less than the careers predominately filled by men. However, research has demonstrated that when women select careers predominately populated by men, they are compensated at a lesser level for comparable skills, effort and/or responsibility (Roth, 2003). This study explores the potential reasons for the differences in career choice and pay differentials within a career field by examining the attitudes of undergraduate business students at a large, southwestern university. We wish to determine if gender, type of prior work experience, and the amount of prior work experience influence salary expectations, career characteristics, job search methods and intensity, internship participation, expected hours required and willingness to work, and sensitivity to gender issues.
\end{abstract}




\section{Theory and Hypotheses}

This study will examine the different work experiences and gender expectations of graduating business students in terms of pay expectations, the importance of various career characteristics, job search methods used and intensity, internship experiences, hours expected and willing to work, and sex-role expectations and sensitivity to gender issues.

\section{Pay Expectations}

The Equal Pay Act of 1963 made it illegal to discriminate in pay on the basis of gender when jobs require equivalent skills, effort and/or responsibility and are performed within the same working conditions (Dessler, 2004). Despite the intervening forty years since the passage of the act, certain professions tend to be male or female-dominated, and the male-dominated careers are typically higher paying (Murrell, Frieze, and Frost, 1991). Jacobs and Steinberg (1990), and Steinberg (1990) found that women are more likely than men to be employed in traditionally feminine occupations which require nurturing social skills, and are generally associated with lower pay. Additionally, men tend to be employed in managerial jobs characterized by a set rate of pay while women often work in freelance settings which offer flexibility but often lack a regular, predictable paycheck (Blau, Ferber and Winkler, 2006). For example, engineering which has a higher percentage of men is higher paying than elementary school teaching, which is more female dominated (Murrell, Frieze, and Frost, 1991). Interestingly, wage gaps in teaching persist even to the university level where men are paid more even when controlling for a wide variety of factors (Hagedorn, 1998; Toutkoujshian, R, \& Conley, V. 2005).

Alsop (2005) claims that many stereotypes are still common in the workplace. A key stereotype is that men are stronger analytically, while women are stronger in communication and strategy. Many of the male-dominated professions, like engineering, are associated with analytical skills, while the female-dominated careers like elementary school teaching, require strong communication skills. However, Roth (2003) conducted a study and determined that women were paid significantly less when compared to men when both held similar Wall Street professions, such as financial analysts. This indicates that the pay difference exists even within the same profession requiring similar skills. Loury (1997), on the other hand, found that while there is a pay gap, this gap is beginning to narrow.

The research of Keaveny and Inderrieden (2000) and Abbott (1993) indicate that women tend to be more satisfied than men with their given level of compensation, even though women are usually paid less. However, Chapple (2001) found that women with higher education value the type of work they do and will not sacrifice career goals or pay for conveniences such as a work location closer to home. Yet Alsop (2005) contradicts Chapple when he discusses women with Master of Business Administration (MBA) degrees and states that in general, women will forgo monetary gain to advance the common good by exceeding the ethical and corporate social responsibility standards. 
As Keaveny and Inderriedan (2000) and Blau, Ferber and Winkler (2006), point out, pay satisfaction is dependent on whether the pay received by an individual equals the amount of pay expected; therefore, if women have lower pay expectations, then they will be satisfied with, and accept, lower pay. Major and Konar (1984) investigated gender differences in pay expectations among a sample of graduate and undergraduate students and found that women did indeed have lower entry-pay expectations and lower career pay expectations. More recently, Alsop (2005) found that men with MBAs were accepting positions with salaries averaging around $\$ 93,066$, while women with MBAs were averaging around $\$ 84,356$ which supports Keaveny and Inderriedan's lower pay expectation theory. This salary finding is also consistent with Wade's (2001) notion that women mat receive less than men in terms of pay because they often do not make adequate salary requests for themselves. However, the average salary information of graduating MBA students found by Alsop (2005) contradicts Loury (1997) who found that the pay gap narrows particularly for educated women.

This study explores pay expectations of graduating business students by examining their salary expectations as they prepare to enter the professional work world.

H1: Male graduating business students will have higher salary expectations than female graduating business students.

In addition to exploring the differences in salary expectations for men and women, this study will also examine the stated desires of graduating business students in terms of the importance of various career characteristics and the use of differing job search strategies.

\section{Career Characteristics}

Murrell, Frieze, and Frost (1991) suggest that women are more concerned with the social aspects of a job while men focus more on the economic conditions. Female students were more inclined to select part-time jobs for the additional benefits associated with the job, such as store discounts and flexibility around studying (Ruscoe and Morgan, 1996). In addition to the pay associated to the job, women tend to choose jobs based on their interest in the job, the ability to work with other people, and the cultural fit between their needs and goals and those of the organization (Murrell, Frieze, and Frost, 1991).

Murrell, Frieze, and Frost (1991) point out that women and men look for different aspects in selecting jobs, such as their interest in the work content and the people they work with. Chapple (2001) explains that working women with children, particularly women with lesser education, prefer to work closer to home. Likewise, married women are less likely to relocate for a career opportunity than men or single women (Duncan, 1996). Additionally, women are more likely to reject an employment offer if it conflicts with family or if they perceive unsuitable job characteristics, such as a perceived culture clash Kulik, 2000). Women also have higher turnover due to family related issues (Keith 
\& McWilliams, 1997). However, men are more likely to quit a job than women, particularly to receive large increases in compensation (Keaveny \& Inderrieden, 2000). It is interesting to note that gender impacts types of turnover; however, there are conflicting findings relating to whether there are gender differences in the wage growth associated with differing types of turnover. Keith and McWilliams (1999) did not find gender differences associated with turnover while Loprest (1992) found that for men turnover resulted in salary increases that were generally twice as large as that for women changing employers.

Heckert, Droste, Farmer, Adams, Bradley, and Bonness (2002) agree that female students will consider multiple job characteristics in additional to salary before selecting which job offer to accept. These characteristics include family life accommodations, pleasant working conditions, travel, interpersonal relations, benefits, and societal contributions. Heckert et al. (2002) indicate that women rate most of these characteristics as being very important, thereby having difficulty prioritizing them.

Heckert et al. (2002) explored whether work experience and gender made a difference on the job characteristics important to current seniors and alumni; however, their study did not take into account the work experience of seniors. Their research did reveal that alumni with less work experience prioritized interpersonal relations and higher pay as being more important than did alumni with more years of work experience.

This study examines if men and women view and rate the importance of job characteristics such as the social aspects of work, work life balance, and culture fit differently. The study also explores whether work experience gained throughout college impacts these values.

H2a: Female graduating business students will put greater importance on the social aspects of work than male graduating business students.

H2b: Female graduating business students will put greater importance on work life balance than male graduating business students.

H2c: Female graduating business students will put greater importance on the culture fit of the organization than male graduating business students.

H2d: Female and male graduating business students with more work experience throughout college will put less importance on pay than students with less work experience.

\section{Job Search Methods and Intensity}

While in the past, university students have relied heavily on informal networks for position openings and for seeking employment, unemployment for more recent graduates has been increasing and possession of degrees is no longer a guarantee for professional employment positions (Villar, Juan, Corominas, and Campell, 2000). 
Villar et al. (2000) focused on students about to graduate and again a year after their graduation to examine job search methods, strategies and intensity. Informal job search strategies rely on gathering information about employment opportunities from social networks, including friends and family, while formal job search strategies include several methods such as newspaper ads, career fairs, internet websites, and career centers to gain information about potential employment. Informal methods are known to allow applicants to learn about potential employment opportunities before these positions are posted, and then to ensure that the employment application or resume is given to key personnel within the organization. Formal search strategies rely on searching for positions that have already been posted and sending out resumes. Job search intensity refers to the time and energy a job seeker spends on securing employment. Villar et al. (2000) concluded that half of their respondents had secured their employment positions through formal channels and that gender did not have a relationship in the way graduates found employment.

Villar et al. (2000) found that students utilizing formal search strategies did not have confidence in their social contacts and that these students had greater job search intensity than their peers relying on informal search strategies. Villar et al. (2000) suggests that it could be a challenge for students to gain entry into professional networks, and Chapple (2001) found that minorities, including women, have a strong disadvantage when using informal networks because they are underrepresented in the work place. DelVecchio and Honeycutt (2002) found that campus career centers were often understaffed and underused by employers, which is another disadvantage to students using formal networks. However, Chapple (2001) reports that women who do use social networking contacts found higher paying positions and had higher job satisfaction than those who did not use or have access to social networks.

Kulik (2000) conducted a study comparing the job search intensity of unemployed men and women at different levels of education. Unlike Villar et al. (2000), Kulik's (2000) research indicates that gender did affect job search intensity and perceptions of unemployed men and women. Kulik determined that men spent more time searching for employment than women, and that women were more likely than men to perceive their chances of landing a job were increased through more intensive job search efforts. Kulik (2000) also determined that while education did not affect job search intensity between men and women, education did affect whether women linked job search efforts to success in finding employment. Women with masters' degrees and above were more likely than women with high school educations to link job search efforts with successfully finding employment. Therefore, it is expected that there is a gender difference in the search for employment opportunities in the terms of the formal and informal methods utilized to gain employment (e.g., attending a career fair, utilizing campus career services, looking through newspaper employment ads, engaging in internet job searches, sending letters directly to companies, and/or asking friends and associates to help identify opportunities) as well as the time spent searching for employment. 
H3a: Female graduating business students will utilize more job search strategies than male graduating business students.

H3b: Male graduating business students will spend more time searching for employment opportunities than female graduating business students.

\section{Work Experience, Internships, and Expectations}

Ruscoe and Morgan (1996) determined that on average, female high school students earn less per hour than their male working classmates. Ruscoe and Morgan (1996) also found in their study on high school students' work experience, that while girls work fewer hours per week on average then boys, both genders experience a large variety of job types including restaurant wait staff, store clerks and stockers, instructors, care providers, lifeguards, referees, disc jockeys, and farmers.

Some students gain work experience through internships. More and more companies are seeing the value of offering internships and are recruiting on college campuses, instead of relying solely on word of mouth (Curry, 2004). Harris, Tanner, and Knouse (1996) discuss the importance of the role that internships done while still a student in college have for securing professional employment upon graduation. In addition, they found a significant difference between the number of Caucasian students and minority students that participated in internship programs. Curry (2004) believes that internships help companies secure talented, loyal employees who can hit the ground running after graduation, and White and Fuller (2002) suggest college internships as a strategy for finding internal auditors in a market where these skills are scarce. Yet, many of the available internships, like the internships discussed by Curry (2004) and White and Fuller (2002), are in the male-dominated fields of business and home building (Murrell, Frieze, and Frost, 1991).

H4a: Male graduating business students are more likely to have held an internship while in college than female college students.

Duncan (1996) suggests that market discrimination which limits the occupational choices of women has begun to erode, thereby opening more doors for women to experience a wider array of career opportunities. Murrell, Frieze, and Frost (1991) found that the majority of professional women work primarily in careers such as elementary school teaching, nursing, social work, office work, or librarianship; however, more women are entering professions that in the past had been traditionally maledominated careers and require long working hours, such as business management and law. While Ruscoe and Morgan (1996) found that both male and female high school students worked a variety of jobs, they found that on average, high school boys worked more hours per week than girls. Duncan (1996) also concluded that white men work significantly more hours per week then white women. These findings of Ruscoe and Morgan (1996) and Duncan (1996) suggest that this trend of males working more hours than females begins in adolescence and continues through one's adult work life. This 
information sets the expectation that business requires long hours and that male graduating business students are more cognizant of this expectation.

H4b: Male graduating business students expect to work more hours per week than female graduating business students upon graduation.

H4c: Male graduating business students will have a higher maximum number of hours per week that they will be willing to work than female graduating business students.

To this point, this study has been examining different work experiences and gender expectations of graduating business students in terms of pay expectations, the importance of various career characteristics, job search methods used and intensity, internship experiences, and hours expected and willing to work. This study will also explore the effect of gender and work experience on sex-role expectations and sensitivity among graduating business students.

\section{$\underline{\text { Sex-Role Expectations and Sensitivity }}$}

Bem (1981) developed a sex-role inventory which looks at femininity, masculinity, androgyny and undifferentiated. Bem uses femininity to refer to characteristics that are stereotypically feminine such as affection, gentleness, understanding, and sensitivity to others. Masculinity describes characteristics that are stereotypically masculine, such as ambitiousness, self-reliance, independence, and assertiveness. Androgyny is a term that integrates femininity and masculinity and describes an individual that processes high scores in having both feminine and masculine characteristics, and undifferentiated identifies individuals with low scores for both feminine and masculine characteristics and therefore have not yet developed their preference. Bem classifies individuals into two groups: those who restrict their behavior to act in accordance with sex stereotypes and those who do not. College students with similar career aspirations may have similar beliefs regarding sex roles (Bem, 1981). Sex roles also affect the career choices of women, in that the most traditional women stay home, somewhat traditional women enter women dominated fields, and non-traditional women choose male dominated careers (DeGregoria, 2001).

Murrell, Frieze, and Frost (1991) found that women with work experience earlier in life held less traditional sex-role attitudes and focused more on career plans. DeGregoria (2001) supports the findings of Murrell, Frieze, and Frost. DeGregoria found that both men and women acquire sex role identities based on gender typed behaviors experienced through adolescence. Sex role behaviors are learned by either participating in specific situations or from generalizing these situations. What individuals have seen and have done helps them to determine how they will act, behave and respond to new and analogous situations. However, DeGregoria also shares that women are now gravitating towards the less traditional careers, particularly educated women, thereby broadening the range of professional opportunities and altering expectations about sex roles (DeGregoria, 2001). 
In addition to sex role stereotypes, Duncan (1996) claims that educated women could be prevented from entering careers which offer greater on the job training and wage growth due to labor market discrimination. He also states that employers are seeking skilled employees, and these potential employees increase their skills through education and experience, and that reduced job training stunts this education and experience. Hansman, Jackson, Grant, and Spencer (1999) assessed graduate students' sensitively to sex and acknowledge that students have differing beliefs based on several criteria, including work backgrounds; yet men in general showed lower sensitivity to gender issues. Their research also indicates that exposure to diversity, especially racial and gender, through college discussions, presentations and readings, leads to increased sensitivity and awareness, which is the primary step toward change. Probst (2003) found that university students who took a diversity course were more likely to be aware that discrimination against African Americans is still present. Roper (2004) and Meacham, McClellan, Pearse, and Greene (2003) found that the majority of students recognize the importance of diversity on campus and feel that it broadens their education, cultural knowledge and awareness. Ponterotto and Pedersen (1993) look at the universal phenomenon of female and racial prejudice and point out that selfawareness of prejudice is needed to prevent or eliminate it. In particular, Ponterotto and Pedersen (1993) look at measuring students' awareness and sensitivity to gender and multicultural issues, such as awareness of discrimination. Ponterotto and Pedersen (1993) believe that attitude formation is developed in the family, and then nourished through the school environment and throughout the world of work, which is similar to the findings of DeGregoria (2001).

H5a: Female graduating business students will have a greater sensitivity to gender issues than male graduating business students.

H5b: Male and female graduating business students who have more work experience will have a greater sensitivity to gender issues.

\section{Methodology}

\section{Subjects and Design}

Data were collected through administering a questionnaire to 187 graduating students majoring in business at a large southwestern university. The original sample consisted of 110 male and 77 female subjects. Nine of the 187 questionnaires were discarded because they were incomplete, which left 105 males and 73 females in the final sample. The average age of the respondents was 23 and the ages ranged from 20 to 35. The ethnicities of the participants in this study were as follows: 127 Caucasians, 36 Hispanics, 5 Asians, 5 African-Americans, and 4 that describe themselves as other. These demographics are representative of the university (University Institutional Research, 2005); however, our sample contains fewer African Americans and a greater number of Hispanics than reported in the 2000 census (U.S. Census, 2000). 


\section{Questionnaire}

The research instrument utilized was divided into five sections: demographic information; professional career plans; college work experience; social values and attitudes scales; and personal attitudes and traits. The demographic information included the students' age, gender, and ethnicity. Information was also gathered to determine if the students' intentions were to work full time in professional careers upon graduation.

The professional career plans section was completed by only 150 students who answered that they were going to work full time in a professional career after graduation. This section consisted of open-ended questions to gather information about the type of jobs students sought expectations for salary, and maximum number of hours students were willing to work. The 29 respondents who answered that they were not going to work full time in a professional career after graduation were asked to skip these questions and then to complete the remainder of the questionnaire.

The questionnaire asked respondents to categorize the importance of job characteristics including cultural fit, social aspects of work, co-workers, excellent pay, personal life prioritization, and career prioritization into one of four categories: very important, important, slightly important, or no importance. We also explored job search intensity and preferred job search methods. In addition to asking the average amount of time per week students spent looking for career employment, we adapted the scale used by Kulik (2000) in her study looking at the job search intensity. Students were asked how often they employed each job search method, using a scale consisting of never, very little, monthly, weekly, and almost daily. The job search strategies listed included newspaper ads, internet job search websites, job fairs, on campus career counseling centers, friends and networking opportunities, and approaching particular companies directly.

The college work experience section gathered information on whether students worked full time, part time, irregularly or not at all during the school year and the summer. We inquired whether the student had held an internship and if it was a paid internship. This section asked students how many hours they worked for these various types of employment. Students were also asked the types of jobs that they held throughout their college experiences, and the total number of semesters that were worked, including the summer semesters.

The social values and attitudes scale section used The Quick Discrimination Index. The Quick Discrimination Index (QDI) was developed by Ponterotto and Pedersen (1993) to determine student's awareness and sensitivity to gender and multicultural issues. It consists of twenty-five statements about gender and race, and asks respondents to rate these statements on a scale of one to five on how strongly they disagree or agree with each statement. 
The personal attitudes and traits section first asks respondents to categorize thirteen statements concerning personal attitudes and traits into true or false. These true/false statements are taken from Crowne and Marlowe (1964). This section of the questionnaire also uses the Bem sex-role inventory (Bem, 1981). The Bem sex-role inventory consists of thirty personality characteristics and asks students to use a scale of never or almost never true (1) to always or almost always true (7) on how each characteristic describes them.

\section{Results}

The independent sample t-test compares means for two groups; therefore, t-tests were used to determine if the means of different variables were statically different between graduating male and female college students. Regression analysis was used when using work experience as the independent variable because it is continuous and therefore does not have distinct groups. Regression analyses were able to access work experience and then predict the value of the different dependent variables.

Hypothesis $\mathrm{H} 1$, describing the relationship between gender and salary expectations, was not supported: $t=-0.889(144), p=0.376$. The data showed that there was no significant difference between the salary expectations between males and females. The mean salary expectation for graduating business students was $\$ 37,116.44$. The mean for female students was $\$ 36,350.88$ and the mean for male students was $\$ 37,414.89$.

This study found no support for hypothesis $\mathrm{H} 2 \mathrm{a}$ which explored the impact of gender on the importance of the social aspects of work: $t=0.080(149), p=0.937$. Hypothesis $\mathrm{H} 2 \mathrm{~b}$ was supported, revealing that there is a gender difference on the importance of work life balance. Female graduating business students place significantly greater importance on achieving work life balance (mean of 3.88) than male graduating business students (mean of 3.57): $t=3.513(149), p \leq 0.001$. This study found support for hypothesis $\mathrm{H} 2 \mathrm{c}$ which examined gender differences and the importance of cultural fit within an organization: $t=2.201(149), p=0.029$. Female graduating business students report significantly greater importance on cultural fit (mean of 3.70 ) than male graduating business students (mean of 3.46). The data supported that there is a significant relationship between work experience and valuing pay: $t=-2.252(98), p=0.027$; however, the data supported the antithesis of hypothesis $\mathrm{H} 2 \mathrm{~d}$. Hypothesis $\mathrm{H} 2 \mathrm{~d}$ predicted that students with more work experience would put less importance on pay, but the data revealed that students with more of work experience placed statistically more significance on excellent pay than graduating business students with less work experience.

Hypothesis $\mathrm{H} 3 \mathrm{a}$, measuring the relationship between gender and the number of job search strategies was not supported: $t=0.571(148), p=0.569$. In addition to the relationship between the total number of strategies used, this study notes there was no significance between gender and preference for each of the various job search strategies. Please refer to Table 1 for the results of the tests for each job search strategy. 
Table 1. Gender and Preferred Job Search Strategies

\begin{tabular}{|c|c|c|c|c|c|}
\hline $\begin{array}{c}\text { Search } \\
\text { Strategy }\end{array}$ & $\mathrm{t}$ & $\mathrm{df}$ & Significance & $\begin{array}{c}\text { Mean Male } \\
\text { Usage } \\
\text { Frequency }\end{array}$ & $\begin{array}{c}\text { Mean Female } \\
\text { Usage } \\
\text { Frequency }\end{array}$ \\
\hline Internet & 0.977 & 148 & 0.330 & 3.85 & 4.03 \\
\hline Networking & -0.235 & 148 & 0.814 & 4.00 & 3.97 \\
\hline Job Fairs & -0.239 & 148 & 0.812 & 2.80 & 2.76 \\
\hline $\begin{array}{c}\text { Career } \\
\text { Centers }\end{array}$ & 0.826 & 148 & 0.410 & 2.59 & 2.74 \\
\hline $\begin{array}{c}\text { Newspaper } \\
\text { Ads }\end{array}$ & 1.328 & 148 & 0.186 & 3.05 & 3.36 \\
\hline $\begin{array}{c}\text { Contact } \\
\text { Potential } \\
\text { Employers }\end{array}$ & -1.047 & 148 & 0.297 & 3.41 & 3.20 \\
\hline
\end{tabular}

Both male and females on average will use a total of four of the job search strategies, but the preference of job search method varies by individual. Table 1 also shows the average frequency each gender uses the following strategies: Internet, networking, job fairs, college career centers, newspaper want ads, and contacting employers directly. Note that the Internet and networking were the strategies used the most often by both genders. No support was found for hypothesis H3b, which examined gender differences and the amount of time spent searching for employment: $t=-1.121(134), p$ $=0.264$.

Hypothesis $\mathrm{H} 4 \mathrm{a}$, describing the relationship between gender and internships while in college, was not supported: $t=-1.66(175), p=0.869$. Additionally, this study shows that there was no significance between gender and whether an internship is paid or non-paid. Please see Table 2 which reports a descriptive breakdown between paid and non-paid internships for students participating in this study.

Table 2. Students with Internships

\begin{tabular}{|c|c|c|c|}
\hline Internship & Total & Women & Men \\
\hline Paid & 26 of 178 & 10 of 73 & 16 of 105 \\
\hline Non-paid & 11 of 178 & 5 of 73 & 6 of 105 \\
\hline $\begin{array}{c}\text { Either Paid or } \\
\text { Non-paid }\end{array}$ & 33 of 178 & 13 of 73 & 20 of 105 \\
\hline
\end{tabular}

Some students held both a paid and a non-paid internship while in college and therefore are counted in the numbers for both paid internships and non-paid internship. The third section of this table counts students only once, even if they fall into both groups. Also note that there were twice as many students with paid internships as with non-paid 
internships. This study did not support hypothesis $\mathrm{H} 4 \mathrm{~b}$ measuring the effect gender has on expected number of hours worked per week after graduation: $t=-1.604(147), p=$ 0.111 . Students expect to work 30 to 65 hours per week, with the mean of 44 hours per week. Male students expect to work an average 45 hours per week after graduation and female students expect to work an average of 43 hours per week after graduation. Hypothesis $\mathrm{H} 4 \mathrm{c}$, which examined gender and the maximum number of hours willing to work after graduation, was also not supported: $t=-0.813(146), p=0.417$. Graduating students were willing to work a maximum of 55 hours per week on average, with a mean of 54.5 hours per week for female graduating business students and a mean of 55.6 for male graduating business students.

This study supported hypothesis $\mathrm{H} 5 \mathrm{a}$, which explored the effect of gender on awareness and sensitivity to gender issues: $t=3.620(176) ; p \leq 0.001$. Female graduating business students had a greater awareness and sensitivity to gender issues with a mean of 77.9 than male graduating business students who had a mean of 71.1. Hypothesis $\mathrm{H} 5 \mathrm{~b}$, describing the relationship between work experience and sensitivity to gender issues, was not supported: $t=-1.909(116), p=0.059$. Graduating business students with more semesters of work experience were not more aware or sensitive to gender issues than graduating business students less semesters of work experience.

\section{Discussion}

The results of the data analysis reveal that graduating business students have similar salary expectations as they prepare to enter the professional working environment. Prior research indicates that men will be better compensated for equivalent positions; however, college men and women expect comparable compensation for their initial post-undergraduate career opportunities. This means that male and female graduating business students expect comparable compensation, but that men are more likely to achieve greater compensation even for careers that are equivalent. As more women continue to enter professions, such as business and law, which have traditionally been dominated by men, it is likely that this gap between the salary expected and the salary achieved will lead to salary dissatisfaction among women. Extant research (Cotter, Hermsen, Ovadia \& Vanneman, 2001; Meyerson \& Fletcher , 2000) shows that the glass ceiling is still in effect and that gender disadvantages are worse at higher career levels than entry level position and that these disadvantages become worse as women progress in their careers. Organizational justice is a theory that examines these perceptions of fairness and considers elements such as pay satisfaction in determining workplace justice evaluations and turnover. Another relevant lens that sheds light on the problems associated with glass ceiling effects is capabilities theory. Capabilities theory explores the interaction of the internal abilities of women in the workplace with their external work environments in order examine workplace justice and social responsibility at work (Cornelius \& Skinner, 2005). In order to be socially just and responsible organizations, companies must have processes in place that eliminate structural barriers to career advancement and are consistent, bias free, and ethical (Leventhal, 1980). This means that organizations will need to continue to eliminate pay 
satisfaction gaps and structural impediments to advancement from entry level positions through higher career level positions.

Gender does effect the expectations of the ranking of the importance of various job characteristics for female graduating business students. The women in the study place greater importance on maintaining a work life balance as well as fitting in within the organization than male graduating business students. This information replicates the findings of Heckert et al. (2002), Murrell, Frieze, and Frost (1991), and Kulik (2000) that women of all ages and different stages in their lives select employment opportunities based on several factors in addition to compensation. While this study had respondents rate different job characteristics on importance, it neglected to have the respondents rank these characteristics in addition to rating them. If male and female respondents differ significantly in ranking these characteristics, it could offer an explanation as to the difference in pay between men and women. Perhaps while gender does not affect salary expectations, gender could play a factor causing women to settle for a lower salary with a company that offered a stronger cultural fit or work life balance for the employee, characteristics not as important to men.

The data contradict the hypothesis that students with more work experience would place less importance on pay, and instead show that students, both male and female, who worked more semesters during college place more importance on pay. This finding on the relationship between work experience and the importance of pay does not support Heckert et al. (2002) findings that higher pay is more important to those with more work experience. Instead the data show that more work experience increased the desire for higher pay. This could be the result of increased self-efficacy on the job market which could lead students to increase their estimated value to employers. Further research in this area would be useful in determining if this is the case and if the higher pay expectations are justified by the knowledge, skills, and abilities acquired in prior work settings.

This study reveals that male and female graduating students will pursue similar job search strategies with similar intensity. Not only do men and women spend similar amounts of time looking for full time employment, neither gender showed preference for particular search strategies. Male and female graduating business students use each of the listed job search strategies in equivalent proportions. Chapple (2001) discusses that women have a disadvantage in using formal networks, such as networking; yet, this study shows that male college students are not utilizing informal networks more than females. This could mean that neither male nor female college students have developed their networks yet, or that women are beginning to make inroads as more women take on leadership roles within organizations and enter male-dominated occupations thereby creating a stronger female network than in the past.

This study did not find a gender difference in graduating college students who had participated in an internship or received compensation for an internship for at least one semester. This finding supports Duncan (1996) that market discrimination has begun to erode and that women have many more opportunities than in the past, a time in which 
internships were much more common for white males. This study looks only at graduating students studying business, which is still considered to be a field that is more male oriented (Alsop, 2005). Over 60 percent of students in this study, whether male or female, were paid for their internship experience and there was no significant difference in the proportions of males and females with internship experience. These finding are especially relevant as increasingly the most popular and effective strategy for recruiting college graduates is the use of internships (Gerdes, 2006).

When comparing the findings of this study and the studies of Duncan (1996) and Ruscoe and Morgan (1996) there is a discrepancy on the expected number of hours worked and the actual number of hours worked by men and women. Duncan (1996) and Ruscoe and Morgan (1996) found that both high school and adult males work significantly more hours per week than their female peers, yet this study found that graduating business men and women had similar expectations of how many hours per week they would work upon graduation. Additionally, both male and female graduating students had similar expectations on the maximum number of hours they would be willing to work per week. The contradicting results between how many hours students expect to work from this study and the gender difference in the amount of hours worked found in previous studies indicate that there is a gap between the expectations of students and the actual number of hours men and women work per week. This means that women will work fewer hours then men per week, even though both genders expect to work the same amount.

The findings of this study support that female graduating business students are more aware and sensitive to gender and racial issues than their male counterparts, which supports the findings of Hansman et al. (1999) who also found that men showed lower sensitivity to gender issues. However, this study did not find support for the belief that additional work experience would increase individuals' awareness and sensitivity to gender issues which conflicted with the beliefs of Ponterotto and Pedersen. Ponterotto and Pedersen (1993) believe that companies' philosophies regarding gender and racial diversity are passed to all employees through actions of tolerating inequality or promoting only white males to leadership positions. They believe that positive organizational behaviors influence what employees see as normal and acceptable behavior regarding racial and gender attitudes. One explanation to account for the difference in this belief of Ponterotto and Pedersen and lack of support from this study could be that even though some students have had more work experience and therefore more exposure to the work world, it does not necessitate that this exposure has been with employers showing positive and sensitive behavior towards gender and race. Students with several semesters of work experience may have worked for companies that were complacent about or even promoted inequality and negative organizational behaviors.

\section{Limitations}

The scope of the study was limited to graduating students majoring in business at a public university in the southwest which may limit the ability to generalize the findings to 
other geographic locations, students of different majors, or non-students. We encourage future researchers to expand our population to other regions to determine if the findings have broader implications than is implied in by this study.

However, attempts have been made to minimize the effects of these limitations on the study by collecting data across all sections of the graduating business capstone course.

There were a limited number of respondents who had held a paid or non-paid internship for at least one semester. Future studies could examine a larger sample size of students with internships, possibly in multiple academic disciplines, to compare with the results of this study. This type of study would also determine if some disciplines are more likely to have internships or receive financial compensation.

Additional limitations may exist in using graduating undergraduate students because of their lack of knowledge about work itself. They know about entry-level employment to some extent, but may not have given much thought to other aspects of employment that they might prefer. Also, they have little need for work life balance at this point because they tend to be unmarried, with no children. Lastly, undergraduate students have not been out in the world work to be banged about enough yet by the unfairness that happens in workplaces.

\section{Conclusion}

Male and female graduating college students utilize similar methods with similar intensity as they search for their initial professional jobs. These individuals have similar expectations for salary and hours required to work. It appears that gender does not impact internship participation or whether the internship is paid or non-paid. However, gender differences do exist in how students rate the importance of specific career characteristics. In particular, female students value cultural fit within the organization and work life balance more significantly than male graduating students. Female students also have significantly greater awareness and sensitivity to gender issues. Regardless of gender, students who have more work experience place greater importance on selecting an organization with excellent pay.

While male and female college students have similar salary expectations, additional research could be done to see when salary expectations begin to differ between men and women. This further research could examine if the salary gap between men and women emerges within the first career position past college, or if the gap is created and enlarged as individuals begin moving up the corporate ladder and become aware of the pay differential.

Lastly, knowing that female students give greater importance to cultural fit and work life balance than males, additional research could be done to determine if gender differences exist, how these individuals prioritize specific career characteristics, and which characteristics they will forego for the characteristics they require. Some of the 
career characteristics that should be examined are social aspects, cultural fit, pay rate, work life balance, promotional opportunity, and flexibility.

This study shows the importance of college work experience and gender on the expectations of graduating business students. It is imperative for companies in today's world to know and understand the expectations of potential employees because these employers are continuously faced with locating, attracting, and hiring the most qualified individuals and then retaining those employees and reducing turnover. Additionally, companies need to ensure that that have a diverse employee base because the economy is continuously becoming more global causing a greater need for understanding of the diverse markets which internal diversity can help alleviate. More or less, when an organization consists of a diverse staff, it better understands and can solve the needs of a diverse market. Realizing that females have a greater awareness and sensitivity to gender issues as well as placing greater value on culture fit and work life balance, and that individuals with more work experience place a greater importance on pay, can help employers alter their company policies and recruiting practices to locate, attract, hire and retain the most qualified women, thereby effectively diversifying their staff and gaining an advantage in the global economy.

\section{References}

Abbott, A. (1993). The sociology of work and occupations. Annual Review of Sociology, 19, 187-210.

Alsop, R. (2005, September 21).Men do numbers, women do strategy: Recruiters see a clear difference between male and female applicants. The Wall Street Journal, R5.

Bem, S. L. (1981). Bem sex-role inventory. Redwood City, CA: Mind Garden.

Blau, F.D., M.A. Ferber \& A.E. Winkler. (2006). The Economics of Women, Men and Work, (Fifth Edition). Pearson Prentice Hall: NJ.

Chapple, K. (2001). Time to work: Job search strategies and commute time for women on welfare in San Francisco. Journal of Urban Affairs, 23, 155-174.

Cornelius, N. \& Skinner, D. (2005). An alternative view through the glass ceiling: Using capabilities theory to reflect on the career journey of senior women. Women in Management Review, 20, 595-210.

Cotter, D. A., Hermsen, J. M., Ovadia, S.\& Vanneman, R. (2001). The glass ceiling effect. Social Forces, 80, 655-682.

Crowne, D.P. \& Marlowe, D. (1964). The approval motive. N.Y.: Wiley.

Curry, Pat. (2004). Hire Education. Builder, 27, 37-39. 
DeGregoria, B. (2001). Women must challenge the limits and expand options in sex role development. Education, 109, 160-164.

DelVecchio, S. \& Honeycutt, E. D. (2002). Explaining the appeal of sales careers: a comparison of black and white college students. Journal of Marketing Education, 24, 56-64.

Dessler, G. (2004). A framework for human resource management (Third Edition). Upper Saddle River, NJ: Prentice-Hall.

Duncan, K. C. (1996). Gender differences in the effect of education on the slope of experience-earning profiles: National longitudinal survey of youth, 1979-1988. American Journal of Economics \& Sociology, 55, 457-472.

Gerdes, L. (2006). The Best Places To Launch A Career. Business Week, Issue 4001, 64.

Hagedorn, L.S. (1998). Implications to postsecondary faculty of alternative calculation methods of gender-based wage differentials. Research in Higher Education, 39, 2, 143162.

Hansman, C. A., Jackson, M. H., Grant, D. F., \& Spencer, L. E. (1999). Assessing graduate students' sensitivity to gender, race, equality and diversity: implications for curriculum development. College Student Journal, 33, 261-269.

Harris, E. W., Tanner, J. R., \& Knouse, S. B., (1996). Employment of recent university business graduates: Do age, gender, and minority status make a difference? Journal of Employment Counseling, 33, 121-129.

Heckert, T. M., Droste, H. E., Farmer, G. W., Adams, P. J., Bradley, J. C., \& Bonness, B. M. (2002).Effect of gender and work experience on Importance of job characteristics when considering job offers. College Student Journal, 36, 344-356.

Jacobs, J. A. \& Steinberg, R. J., (1990). Compensating Differentials and the MaleFemale Wage Gap: Evidence from the New York State Comparable Worth Study. Social Forces, 69, 2, 439-468.

Keaveny, T. J., \& Inderrieden, E. J. (2000).Gender differences in pay satisfaction and pay expectations. Journal of Managerial Issues, 12, 363-380.

Keith, K. \& McWilliams, A., (1999). The Returns to Mobility and Job Search by Gender: Additional Evidence from the NLSY, Industrial \& Labor Relations Review, 52, 3, 460477.

Keith, K. \& McWilliams, A., (1997). Job Mobility and Gender-Based Wage Growth Differentials. Economic Inquiry, 35,2, 320-33. 
Kulik, L. (2000). Jobless men and women: a comparative analysis of job search intensity, attitudes towards unemployment, and related responses. Journal of Occupational \& Organizational Psychology, 73, 487-501.

Leventhal, G. S. (1980).What should be done with equity theory? New approaches to the study of fairness in social relationships. In K.J. Gergen, M.S. \& R.H. Willis (Eds.) Social exchange: Advances in theory and research, p. 22-55, New York: Plenum Press.

Loprest, P. J., (1992). Gender Differences in Wage Growth and Job Mobility. American Economic Review, 82, 2, 526-32.

Loury, L. D. (1997).The gender earnings gap among college-educated workers. Industrial \& Labor Relations Review, 50, 580-594.

Major, B. \& Konar, E., (1984). An Investigation of Sex Differences in Pay Expectations and Their Possible Causes. Academy of Management Journal, 27, 777-792.

Meacham, J., McClellan, M., Pearse, T., \& Greene, R. (2003). Student diversity in classes and educational outcomes: student perceptions. College Student Journal, 37, 627-643.

Murrell, A. J., Frieze, I. H. \& Frost, J. L. (1991). Aspiring to careers in male- and femaledominated professions: A study of black and white college women. Psychology of Women Quarterly, 15, 103-127.

Meyerson, D. \& Fletcher, J. (2000). A modest manifesto for shattering the glass ceiling. Harvard Business Review, 78, 127-140.

Ponterotto, J. G. \& Pedersen, P. B. (1993). Preventing prejudice: A guide for counselors and educators. Newbury Park, CA: Sage Publications.

Probst, T. (2003). Changing attitudes over time: assessing the effectiveness of a workplace diversity course. Teaching of Psychology, 30, 236-240.

Roper, L. D. (2004). Do students support diversity program? Change, 36, 48-52.

Roth, L. M. (2003). Selling women short: A research note on gender differences in compensation on Wall Street. Social Forces, 82, 783-803.

Ruscoe, G. \& Morgan, J. F. (1996). Students who work. Adolescence, 31, 625-631

Steinberg, R. (1990). Social Construction of Skill: Gender, Power and Comparable Worth. Work and Occupations, 17, 449-482. 
Toutkoujshian, R, \& Conley, V. (2005). Progress for women in academe, yet inequities persist: Evidence from NSOPF: 99. Research in Higher Education, 46, 1, 1-28.

University Institutional Research, (2005). Retrieved on September 20, 2006 from http://www.irp.txstate.edu/fb/et/index.htm.

U.S. Census Bureau, (2000). Retrieved on September 20, 2006 from http://www.census.gov/main/www/cen2000.html.

Villar, E., Juan, J., Corominas, E., \& Capell, D. (2000). What kind of networking strategy advice should career counselors offer university graduates searching for a job? British Journal of Counseling, 28, 389-410.

Wade, M. E. (2001). Women and salary negotiation: The costs of self-advocacy Psychology of Women Quarterly, 25, 1, 65-76

White, S. D. \& Fuller, W. H. (2002). Managing a student internship. The Internal Auditor, 59, 36-40. 